\title{
Prediction of genetic gain in progeny test of Samama [Anthocephalus macrophyllus (Roxb.) Havil.] in West Seram District, Maluku Province, Indonesia
}

\author{
Ambar Dwi Suseno ${ }^{1,2}$, Yossa Istiadi ${ }^{2}$, and Sata Yoshida Srie Rahayu ${ }^{2}$
}

${ }^{1}$ Directorate General Control of Watershed and Protected Forest, Ministry of Environment and Forestry of the Republic of Indonesia, Gedung Manggala Wanabakti Blok I Lt. 2, Jl. Jend. Gatot Subroto, Jakarta 10270, Indonesia

${ }^{2}$ Study Programme of Environmental Management, Graduate School of Pakuan University, Jl. Pakuan Kotak Pos 452 ,

Bogor 16129, Indonesia

Corresponding author: Ambar Dwi Suseno, ambardwisuseno@gmail.com

\begin{abstract}
The research objective is to find out genetic variation, estimated heritability value and the expected genetic gain of Samama [Anthocephalus macrophyllus (Roxb.) Havil.] on variation in stem diameter and plant height as superior seed producers. The research was conducted in Uraur Village, West Seram Regency, Maluku Province. The trials consisted of 80 families. All of the trials were laid out in randomized complete block designs (RCBD), 4-trees plots with 4 replications (blocks) at spacing of $5 \mathrm{~m} \times 2 \mathrm{~m}$. Data collection was carried out for 2 months (February to March 2020) and was focused on observing growth variations and genetic parameters in the progeny trial block at 4 years of age including plant height and diameter at breast height. The results of this study indicate that there are variations in growth, where the Anova test results show very significant differences in the plant height parameters namely Family $(\mathrm{F}=3.417 \mathrm{p}<0.01)$, Block $(\mathrm{F}=437.465 \mathrm{p}<0.01)$ and Family and Block Interactions $(\mathrm{F}=3.351 \mathrm{p}<0.01)$. The stem diameter parameters also showed very significant differences, namely Family $(\mathrm{F}=2.785 \mathrm{p}<0.01)$, Block $(\mathrm{F}=353.095 \mathrm{p}<0.01)$ and Family and Block Interaction $(\mathrm{F}=2.611 \mathrm{p}<0.01)$. The value of family heritability and individual heritability on plant height characters belonged to a high category with a family heritability value of 0.7213 and individual heritability value of 0.8811 , while the stem diameter character for individual heritability was high with a value of 0.4406 but family heritability was moderate with value of 0.5204 . The value of genetic correlation was high and positive and generally shows a greater value than the phenotypic correlation. Genetic correlation values ranged from 0.967 while phenotypic correlation values ranged from 0.8944 . The highest selection priority was found in the height of the stem with a weight constant of 0.239 . Predicted expected genetic gain was $3.0 \%$ for diameter parameter and $3.2 \%$ for height parameter.
\end{abstract}

\begin{abstract}
ABSTRAK
Objektif dari penelitian ini adalah menemukan variasi genetik, taksiran nilai heritabilitas serta peluang perolehan expected genetic gain tanaman Samama [Anthocephalus macrophyllus (Roxb.) Havil.] pada variasi diameter dan tinggi pohon sebagai penghasil benih unggul. Penelitian dilakukan di Desa Uraur Kabupaten Seram Bagian Barat Provinsi Maluku. Percobaan ini menggunakan 80 famili. Penelitian ini dibangun dengan desain randomized completely block design (RCBD), jarak tanam 5 x 2 m, 4 ulangan (blok) dan 4 treesplot. Pengumpulan data dilakukan selama 2 bulan (Februari sampai dengan bulan Maret 2020) memfokuskan pada pengamatan variasi pertumbuhan dan parameter genetik yang berada di blok uji keturunan pada umur 4 tahun meliputi tinggi dan diameter setinggi dada. Hasil Penelitian ini menunjukkan bahwa terdapat variasi pertumbuhan, dimana dari hasil uji Anova menunjukkan perbedaan sangat nyata pada parameter tinggi yaitu Famili $(\mathrm{F}=3,417 \mathrm{p}<0,01)$, Blok $(\mathrm{F}=437,465 \mathrm{p}<0,01)$ dan Interaksi Famili dan Blok $(\mathrm{F}=3,351 \mathrm{p}<0,01)$. Pada parameter diameter juga menunjukkan perbedaan sangat nyata yaitu Famili $(\mathrm{F}=2,785 \mathrm{p}<0,01)$, Blok $(\mathrm{F}=353,095 \mathrm{p}<0,01)$ dan Interaksi Famili dan Blok $(\mathrm{F}=2,611 \mathrm{p}<0,01)$. Nilai heritabilitas famili dan heritabilitas individu pada karakter tinggi tanaman memiliki kategori tinggi dengan nilai heritabilitas famili 0,7213 dan nilai heritabilitas individu 0,8811, sedangkan pada karakter diameter tanaman untuk heritabilitas individu tergolong tinggi dengan nilai sebesar 0,4406 namun heritabilitas famili tergolong sedang dengan nilai 0,5204. Nilai korelasi genetik bernilai tinggi dan positif serta secara umum menunjukkan nilai yang lebih besar dibandingkan dengan korelasi fenotipik. Nilai korelasi genetik berkisar 0,967 sedangkan nilai korelasi fenotipiknya berkisar 0,8944. Prioritas seleksi tertinggi ditemukan pada tinggi batang dengan nilai konstanta bobot sebesar 0,239. Prediksi expected genetic gain diperoleh 3,0\% untuk parameter diameter dan 3,2\% untuk parameter tinggi.
\end{abstract}

Keywords: Samama, heritability, phenotypic, expected genetic gain, tree diameter, tree height 


\section{INTRODUGTION}

Samama [Anthocephalus macrophyllus (Roxb.) Havil.] is one of the superior plants of Maluku Province which has fast growth, can grow in broad climate distribution and has high economic value. Samama also has a smooth wood texture and straight wood fiber direction. The red wood color is also quite unique and has a strong and durable wood. Taking into account the nature of Samama plants the fast-growing, have high end product value and can be processed extensively such as for sawn timber, plywood, plywood or veneer as well as being a type of native plant of Indonesia, the development of this plant must be carried out continuously to be able to meet the ecological and economic needs community (Mulyana, 2010).

Samama species development still faces many obstacles related to seed quality where the seeds used in planting activities often do not pay attention to genetic, physical and physiological qualities.

In the framework of providing superior seeds of Samama plants to increase productivity of Samama plants, the Maluku and Papua Forest Plant Seedling Centers have established a Samama Seedling Seed Orchad in the Uraur Village, West Seram Regency, Maluku Province. The concept of establishing Seedling Seed Orchad conducted combines the concept of tree breeding with conservation of genetic resources where the construction of Progeny test blocks and Seedling Seed Orchad blocks are built separately but are still in the same area. The concept of developing Seedling Seed Orchad was born as a solution with the increasingly minimal presence of Samama plant genetic material in its natural habitat. This research was conducted to determine the best growth variation, genetic parameters, family (Mother Plant) and predicting the expected genetic gain in the 4-year-old Samama progeny test block which will later be used as the basis for selecting the Seedling Seed Orchad block.

\section{METHODS}

The study was conducted on the Samama Progeny test block located on the land belonging to the Maluku Protestant Ghurch Synod located in Uraur Village, Kairatu District, West Seram District, Maluku Province with an area of $1.28 \mathrm{Ha}$ of the total area of the Seedling Seed Orchad of $5 \mathrm{Ha}$ with a height of \pm 15 meters above sea level ( $\mathrm{m}$ asl). Based on the seed zone, this location belongs to the lowland rain seed zone, the red yellow podsolic soil type with red sandy clay texture. This land is quite fertile, characterized by the presence of forests with teak plants around the study site.

The research material used was 4-year-old Samama plant in progeny test blocks, experimental design maps, and plant measurement sheets (tally sheet). The equipment used is measuring poles, diameter tape, brushes, and computers.

The experimental design used in the construction of the Samama Progeny test block is consisted of 80 families. All of the trials were laid out in randomized complete block designs (RCBD), 4-trees plots with 4 replications (blocks) at spacing of $5 \mathrm{~m} \times 2 \mathrm{~m}$.

The number of plants observed was 1,280 plants. Plant heights were measured using poles from the base of the tree to the highest growing point. The stem diameters were measured using a diameter tape (diameter tape) at breast height $( \pm 1.30 \mathrm{~m})$. Data were analyzed follows the equation:

\section{Yijkl $=\mu+B i+F j+B F i j+E i j k l$}

Where:

Yijkl = individual $\mathrm{k}$-tree observations of the $\mathrm{j}$-th family in the i-th block

$\mu \quad=$ general average

$\mathrm{Bi} \quad=$ i-th block effect

$\mathrm{Fj} \quad=\mathrm{j}$-th Family effect

BFij = interaction effects of the $\mathrm{i}$-th block and j-family

eijkl $=$ random error on observation to ijkl

Estimated value of individual heritability $\left(\mathrm{h}^{2} \mathrm{i}\right)$ and family heritability $\left(h^{2} f\right)$ are calculated using the following formula (Hardiyanto, 2007):

$$
h^{2} \mathrm{i}=\frac{4 \sigma^{2} \mathrm{f}}{\left(\sigma^{2} \mathrm{f}+\sigma^{2} \mathrm{bf}+\sigma^{2} \mathrm{e}\right)} \quad \mathrm{h}^{2} \mathrm{f}=\frac{\sigma^{2} \mathrm{f}}{\left(\sigma^{2} \mathrm{f}+\sigma^{2} \mathrm{bf} / \mathrm{b}+\sigma^{2} \mathrm{e} / \mathrm{n} b\right)}
$$

Where:

$\sigma^{2} \mathrm{f}=$ Components of family variance (Mother Plant)

$\sigma^{2} \mathrm{bf}=$ components of the variance of block and family interactions (Mother Plant)

$\sigma^{2} \mathrm{e}=$ component error variance

$\mathrm{n}=\mathrm{=}$ the harmonic mean of the number of trees per plot

$\mathrm{b} \quad=$ the average harmonic number of blocks

$\mathrm{f}=$ average harmonic number of families (Mother Plant)

According to Cotterill and Dean (1990) in Indrioko et al. (2016) Heritability values are explained as follows:

Low: $\mathrm{h}^{2} \mathrm{f} \leq 0.40$ and $\mathrm{h}^{2} \mathrm{i} \leq 0.1$

Moderate: $0.40 \leq \mathrm{h}^{2} \mathrm{f} \leq 0.60 \& 0.10 \leq \mathrm{h}^{2} \mathrm{i} \leq 0.30$

Height: $h^{2} f>0.60$ and $h^{2} i>0.30$ 
Genetic correlation between two traits (rxy) is calculated using the following formula(Williams et al., 2002):

$$
\boldsymbol{r x y}=\frac{\sigma_{x y}^{2}}{\sqrt{\sigma_{x}^{2} \sigma_{y}^{2}}}
$$

Where:

rxy = covariance of two properties ( $\mathrm{x}$ and $\mathrm{y})$ at the family level (Mother Plant)

$\sigma^{2 \mathrm{x}}=$ variant component for $\mathrm{x}$ properties at the family level (Mother Plant)

$\sigma^{2 y}=$ component variance for $\mathrm{y}$ properties at the family level (Mother Plant)

Selection of the best Family (Mother Plant) based on the selection index value (I):

$\mathrm{I}=[\mathrm{bh} * \mathrm{H}+\mathrm{bd} * \mathrm{D}]$

$b=\mathrm{P}_{\mathrm{f}}-1 * \mathrm{G}_{\mathrm{f}} *$ a... (Yamada, 1977)

Where:

I $=$ Index value

bh = high weight value

bd = weight value of diameter properties

$\mathrm{H} \quad=$ high

$\mathrm{D}=$ diameter

$\mathrm{b}=\mathrm{a}$ matrix of the weight values of each trait

$\mathrm{P}_{\mathrm{f}}{ }^{-1}=$ inverse matrix phenotypic family variance and covariance

$\mathrm{G}_{\mathrm{f}} \quad=$ matrix family of variance and covariance components

a = each relative economic coefficient vector is calculated as the inverse of the standard deviation phenotypic family

To estimate the expected genetic gain, used a formula according to Zobel and Talbert (1984):

$\mathrm{G}=\mathrm{H}^{2} \times \mathrm{S}$ or $\mathrm{G}=\mathrm{H}^{2} \times \mathrm{I} \times \mathrm{s}_{\mathrm{p}}$

Where:

$\mathrm{G} \quad=$ estimated genetic gain (Expected genetic gain)

$\mathrm{H} \quad=$ heritability

$\mathrm{S} \quad=$ Differential Selection

$\mathrm{s}_{\mathrm{p}} \quad=$ Standard Deviation of the Phenotype
To find out the success of Samama plant life in the Samama progeny test block, the percentage of plant life is calculated using the formula:

$\mathrm{Pi}=(\mathrm{ni} / \mathrm{n}) \times 100 \%$

Where:

$\mathrm{Pi}=$ percentage of plant life

ni $=$ The number of plants living in the census field

$\mathrm{n} \quad=$ The number of plants that should be present

\section{RESULTS AND DISGUSSION}

\section{Adaptation and Growth}

The adaptability shown by percentage Samama plant life in the progeny test block in Uraur Village, West Seram District, Maluku Province up to 4 years is relatively good. In general, the plant growth rate is quite good where there are 51 families that have a life percentage above $75 \%$ and 29 families have percentage life $50 \%-74 \%$.

Based on data on the number of individuals in the plot (4 trees per plot), on average percentage plant life in the plot is $75 \%$ or the average number of plants that live in each plot is 3 plants. Growth data of height and diameter of Samama plants in the progeny test block also showed a good growth rate. Percentage Samama plant life is quite high in the progeny test block probably caused by the nature of Samama plants that are able to grow and adapt to various conditions of the place to grow, relatively free from pests and serious diseases and relatively easy silvicultural treatment (Krisnawati et al., 2011). Surip et al. (2017) reported that Jabon Merah plant growth was still quite high in the first generation progeny test plot which was built in Wonogiri where land conditions were marginal land with a low average annual rainfall (1,645 $\mathrm{mm} /$ year). Percentage plant life is an important factor in plant breeding actions to maintain the validity of data analysis (Chambers and Borralho, 1997 in Sumardi et al., 2018).

The results of this study indicate the average growth of Samama plants for height parameters is $5.735 \mathrm{~m}$ with a range between $5.39-6.20 \mathrm{~m}$, while the average diameter parameter growth is $6.33 \mathrm{~cm}$ with a range between $5.70-6.70 \mathrm{~cm}$. The height and diameter growth value of Samama or better known as Jabon Merah [Anthocephalus macrophyllus (Roxb.) Havil.] is better than the growth of height and diameter of Jabon Putih [Anthocephalus cadamba.], this can be proven in the results of Junaedi's research (2018) on the growth of 4-year-old Jabon Putih [Anthocephalus cadamba.] in Riau, the average height growth is $4.17 \mathrm{~m}$ and the average diameter is $5.15 \mathrm{~cm}$. The difference is thought to be caused by differences in plant genetic material, site 
conditions and silvicultural treatment. Differences in growth of white A. cadamba between locations were also reported by Krisnawati et al. (2011) and Seo et al. (2015).

In general, the growth rate of plant diameter $(\mathrm{StDev}$ $=3.779$ mean $=7.056)$ is faster than the growth rate of plant height $(\mathrm{StDev}=3.058$ mean $=6.423)$. The phenotypic variation in diameter $\left(s^{2}=20.592\right)$ looks greater when compared to the phenotypic variation in plant height $\left(s^{2}=15.52\right)$. However, in general the phenotypic variation of plants showed that the Samama plants in the progeny test block still had normal plant growth (Figure 1).

\section{Genetic Variation in Growth}

Analysis of variance in the 4 year old Samama progeny test block is presented in App. 1, that the Samama plant in the progeny test block in Uraur Village, West Seram Regency, Maluku Province,showed very significant differences in the height parameters namely Family ( $\mathrm{F}=3,417 \mathrm{p}<0.01)$, Block $(\mathrm{F}=437,465 \mathrm{p}<0.01)$ and Family and Block Interaction $(\mathrm{F}=3.351 \mathrm{p}<0.01)$. The diameter parameters also showed very significant differences, namely Family $(\mathrm{F}=2.785 \mathrm{p}<0.01)$, Block $(\mathrm{F}=353.095$ $\mathrm{p}<0.01)$ and Family and Block Interaction $(\mathrm{F}=2.611$ $\mathrm{p}<0.01$ ). The influence of family factors (mother plant) and blocks on height and diameter are also shown in the results of the study of Mashudi and Baskorowati (2015) on the Alstonia scholaris island aged 2 years, Kinho et al. (2015) on ebony (Diospyros rumphii) one year old, Santos et al. (2015) in Eucalyptus badjensis, Haryjanto et al. (2014) at the life (Ficus variegata) at 8 months, Yudohartono (2013) at the white jabon (Anthocephalus cadamba) aged 5 and 8 months, Araucaria cunninghamii aged 18 and 5 years (Setiadi, 2010; Setiadi and Susanto, 2012). Hadiyan (2010) in sengon (Falcataria moluccana) at 4 months, and in Mahfudz et al. (2010) in merbau (Intsia bijuga) aged 18 months.

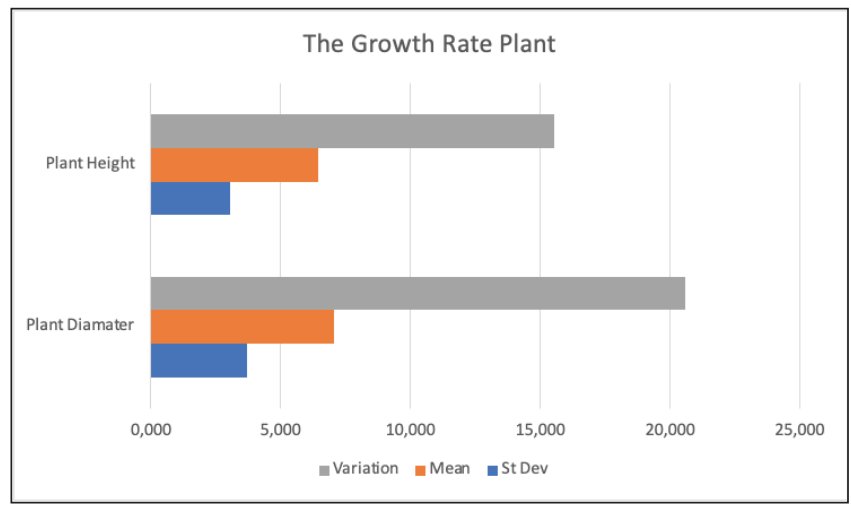

Figure 1. The growth rate of plants.

The difference is very evident in the source of block variation, giving the sense that there are variations in the place of growth in one planting location gives a real influence on the growth and height of Samama plants. Thus the making of blocks in the Progeny test Samama of the plant native from Maluku Province becomes very effective in anticipating the effect of different places of growth on plant growth. In accordance with the purpose of making plant blocks as stated Na'iem (2007) that the building of the block aims to minimize the variation of the existing or presumed environment of the families tested in each block, so that in each block of the plant environmental conditions must be as homogeneous as possible.

\section{Estimated Heritability Value}

All traits observed, the proportion of the variance component to the largest total variation is shown at the source of variation in the plot $(74.50 \%-86.20 \%)$, and then the variance component interaction of the family x block $(10.60 \%-21 \%)$ and the smallest at component of family variance $(3.20 \%-4.50 \%)$. The diameter of the stem has a greater proportion of the variance component in the plot $(86.20 \%)$ compared to the plant height $(74.50 \%)$, but instead the high nature has a greater proportion of the variance component interaction of the family $x$ block $(21 \%)$ than the diameter (10.60\%) (App. 2).

Based on the division of values according to heritability Cotterill and Dean (1990) in Indrioko et al. (2016) Family heritability and individual heritability at high characters have a high category with family heritability $>0.60\left(\mathrm{~h}^{2} \mathrm{f}=0.7213\right)$ and individual heritability $>0.30\left(\mathrm{~h}^{2} \mathrm{i}=0.8811\right)$ while those with diameter are categorized as high. For individual heritability with an individual heritability value $>0.30$ $\left(\mathrm{h}^{2} \mathrm{i}=0.4406\right)$ for moderate family heritability is $0.40 \leq$ $\mathrm{h}^{2} \mathrm{f} \leq 0.60\left(\mathrm{~h}^{2} \mathrm{f}=0.5204\right)$.

The results also showed that the family heritability value was not always greater than the individual heritability value as seen in the high parameter $\left(\mathrm{h}^{2} \mathrm{f}=\right.$ $\left.0.7123<\mathrm{h}^{2} \mathrm{i}=0.8811\right)$ even though the Diameter parameter showed different results $\left(\mathrm{h}^{2} \mathrm{f}=0.5204>\mathrm{h}^{2} \mathrm{i}=\right.$ 0.4406). The high value of individual heritability compared to family heritability is usually obtained after selection, as in the results of Sutrisno's research (2007) on Acacia mangium which reported that individual heritability was higher than family heritability after thinning. Likewise with the results of studies on other types of conifers (Pinus sylvertris) aged 10 years.

In general these results identify that the variation in the growth of high traits is quite strongly influenced by genetic factors. Based on the value of family heritability on the high character that has a high value in the progeny test block indicates that family selection in the Seedling Seed Orchad block based on plant height properties has the potential to provide greater genetic gain. 


\section{Estimated Genetic Correlation Value}

Genetic correlations are high and positive and generally show greater values compared to phenotypic correlations (Table 1). Genetic correlation values ranged from 0.967 while phenotypic correlation values ranged from 0.8944 . Hardiyanto (2008) suggested that phenotypic correlations are correlations between values measured from two traits in a population, whereas genetic correlations are correlations between breeding values for different traits and are mainly caused by genes that affect more than one trait (pleiotrophy). Phenotypic correlation is basically a complex function of genetics and environment that has little use as a reference to genetic conditions (White et al., 2007).

Table 1. Genetic and phenotypic correlations between diameter and plant height traits of Samama.

\begin{tabular}{|c|c|c|}
\hline Parameters & Plant Height & Stem Diameter \\
\hline Plant height & - & 0.967 \\
\hline Diameter & 0.8944 & - \\
\hline
\end{tabular}

Note: genetic correlation (above diagonal), phenotic correlation (below diagonal)

Table 1 also shows that the growth of height and diameter growth have a fairly close and positive close relationship. In relation to the efficiency of the selection work to be carried out in the seedling nursery block, one parameter can be used, namely selection based on height or diameter. This is because genetic improvement of height parameters will be followed by genetic improvement of plant diameter parameters. Genetic correlations between height and diameter are high in forestry plants, including Intsia bijuga (Mahfudz, 2013), Falcataria moluccana (Ismail and Hadiyan, 2008; Hadiyan, 2010), Aracauria cunninghamï (Setiadi, 2010), and Shorea parvifolia (Prasetyawati, 2009).

\section{Determination of the Best Family}

In general, progeny test is carried out for spacing selection in a tree plot that will be converted into a seedling seed orchad. Progeny test of Samama plants conducted in Uraur Village, West Seram Regency, Maluku Province is an progeny test to obtain selected family information that will be used for family selection in the Seedling Seed Orchad block (KBS), where the Progeny test and KBS tests are built in two separate populations. Family ranking (Mother Plant) in breeding programs is a very important factor because family ranking (Mother Plant) is a measure of the performance of the family (Mother Plant) tested in an Progeny test which can later be used as a basis for selection and development of more breeding programs continued (Halawane, 2013).
Table 2. The stem diameter and plant height of Samama.

\begin{tabular}{|c|c|c|}
\hline No. & Parameters & b \\
\hline 1 & High & 0.239 \\
\hline 2 & DBH & 0.027 \\
\hline
\end{tabular}

This study produces a positive value at the value of "b" or the weight constant for each of the measured quantitative genetic parameter traits, where the value of the high parameter weight constant is 0.239 and the diameter parameter weight constant is 0.027 (Table 2). This shows that the selection of the traits of the quantitative genetic parameters for tree selection is the height or criteria for determining the tree or family to be chosen.

The best family / ranking family (Table 3) for family selection in the progeny test in this study was determined from the index value. The index value is a combined value of two parameters of height and diameter. Table 3 shows that family number 50 has the largest index value of 1.67 with an average value of height is $6.205 \mathrm{~m}$ and diameter of $6.802 \mathrm{~cm}$, the acquisition of this index value also indicates that family number 50 is the best family (rank I) .Purwanta (2012), states that family ranking in a breeding program will be easier if it is based on one trait, however if based on many traits of breeders it will be faced with the fact that the ranking of the best family in one trait is not always the best in another. The results of this study indicate that the index value will facilitate the ranking when there is a family that gives the best value in one of the parameter properties but not in the other parameters as described in families number 73 with 3, and 27 with 23 (Table 4).

Table 3. The top ten families of Samama.

\begin{tabular}{|c|c|c|c|c|}
\hline Fam & Index & Rank & $\begin{array}{c}\text { Height } \\
(\mathbf{m})\end{array}$ & $\begin{array}{c}\text { DBH } \\
(\mathbf{c m})\end{array}$ \\
\hline 50 & 1.67 & 1 & 6.205 & 6.802 \\
\hline 31 & 1.61 & 2 & 5.957 & 6.760 \\
\hline 13 & 1.60 & 3 & 5.951 & 6.733 \\
\hline 11 & 1.60 & 4 & 5.961 & 6.635 \\
\hline 75 & 1.60 & 5 & 5.939 & 6.780 \\
\hline 65 & 1.60 & 6 & 5.952 & 6.594 \\
\hline 73 & 1.60 & 7 & 5.946 & 6.646 \\
\hline 3 & 1.60 & 8 & 5.924 & 6.709 \\
\hline 27 & 1.59 & 9 & 5.914 & 6.539 \\
\hline 23 & 1.59 & 10 & 5.918 & 6.498 \\
\hline
\end{tabular}


Table 4. Predicted value of expected genetic gain.

\begin{tabular}{|c|c|c|c|c|}
\hline No. & Trait & Mean & S.D & $\begin{array}{c}\text { Expected } \\
\text { Genetic } \\
\text { Gain }\end{array}$ \\
\hline 1 & Diameter & 5.735 & 1.1193 & $0.17(3.0 \%)$ \\
\hline 2 & Height & 6.333 & 1.332 & $0.22(3.2 \%)$ \\
\hline
\end{tabular}

\section{Expected Genetic Gain Prediction}

Genetic gains is a response to selection, whereas selection is based on the principle that the average genetic value of the selected individual will be better than the average value of all individuals in the population. When the genetic gain is calculated on the population before selection, it is called the expected genetic gain, while the genetic gain calculated based on existing controls or unimproved seeds is called the realized genetic gain.

Table 4 shows that Expected Genetic Gain on diameter and height parameters at the age of 4 years showed results that did not differ too far. This can illustrate the magnitude of the intensity of the selection that will be applied to the seedling nursery block in order to increase genetic gain (read: increased production and quality). These results are related to the results of the family heritability value at the high parameter 0.72 and the heritability value at the diameter parameter 0.52. It appears that with a large heritability value, the chances of genetic enhancement that can be obtained will be even greater. While the value of heritability will increase with increasing plant age, this is in accordance with the opinion of Kien et al. (2009), which states that an increase in heritability as a result of increasing plant age may also occur due to a competitive effect on older stand age, which can lead to an estimate of heritability that is greater than it should be. Genetic enhancement also becomes higher with higher levels of selection intensity.

\section{GONGLUSION}

Based on Data analysis and discussion above, then in this study several conclusions can be drawn as follows:

Samama plant growth 4 years old in the progeny test block in Uraur Village, West Seram Regency, Maluku Province has growth variation, which is from the Annova test results showed very significant differences in the height parameters namely Family $(\mathrm{F}=3.417 \mathrm{p}$ $<0.01)$, Block ( $\mathrm{F}=437.465 \mathrm{p}<0.01)$ and Family and Block Interaction $(\mathrm{F}=3.351 \mathrm{p}<0.01)$. The diameter parameters also showed very significant differences, namely Family $(\mathrm{F}=2.785 \mathrm{p}<0.01)$, Block $(\mathrm{F}=353.095$ $\mathrm{p}<0.01)$ and Family and Block Interaction $(\mathrm{F}=2.611$ $\mathrm{p}<0.01)$.

Quantitative genetic characteristics of Samama plants in the progeny test block indicate that the family heritability and individual heritability values in plant height characters have a high category with a family heritability value of 0.7213 and an individual heritability value of 0.8811 , whereas in plant diameter characters for individual heritability are high with value of 0.4406 but family heritability is moderate with a value of 0.5204. Another quantitative genetic characteristic is the value of high and positive genetic correlations and generally shows greater values compared to phenotypic correlations. Genetic correlation values ranged from 0.967 while phenotypic correlation values ranged from 0.8944. Expected expected genetic gain is obtained $3.0 \%$ for diameter parameters and $3.2 \%$ for height parameters.

The top ten families that can be used as producers of superior seeds based on the calculation of successive index values are families number 50, 31, 13, 11, 75, 65, 73, 3, 27, and 23.

\section{AKNOWLEDGEMENTS}

The first author thanks Ir. Mintarjo, MMA. as Director of Forest Plant Seedling of the Ministry of Forestry and Junediyono, S. Hut., M.Si. as Head of Waehapu Batu Merah watershed and protected forests management unit (BPDASHL Waehapu Batu Merah) who has supported and given permission to carry out this research. Dr. Arif Nirsatmanto, a Researcher at the Center for Forest Biotecnology and Tree Improvement, Ministry of Environment and Forestry, Nasrullah Hamzah, a staff at the seed forest unit Region II (BPTH Region II), who was willing to accept author's consultations on the processing and analysis of quantitative genetic data, as well as A. Rusdi and all BPDASHL Waehapu Batu Merah staff, has assisted in conducting data collection. This paper is part of the author's thesis at the Environmental Management Study Program at Pakuan University.

\section{REFERENGES}

Adam, J.P., Roussea, R.J. \& Adam, J.C. (2007). Genetic performance and maximizing genetic gain through direct and indirect selection in cherrybark oak. Silvae Genetica 56 (2): 80-87.

Halawane, J. (2013). Genetic variation in growth and specific gravity of teak wood test for 15-year-old progeny in Ngawi and Bojonegoro KPH [Thesis]. Yogyakarta (ID): Forestry Postgraduate Program Faculty of Forestry, Gadjah Mada University.

Haryjanto, L, Prastyono \& Yuskianti, V. (2014). Variations in growth and genetic parameters in the three plots of life test (Fixus variegata Blume) in Bantul. FPTH 8 (3): 137-151.

Hardiyanto, E.B. (2008). Diktat Course for Advanced Tree Breeding. Graduate program. Faculty of Forestry, Gadjah Mada University, Yogyakarta. Unpublished. 
Indrioko, S, Hardiwinoto, S. \& Purwanta, S. (2016). Improvement of Teak Quality in Plantations of Progeny in Perum Perhutani Kph Ngawi and Cepu Kph. Proceedings of the Symbion (Symposium on Biology Education), Biology Education Study Program, FKIP, Ahmad Dahlan University. p-ISSN: 2540-752x e-ISSN: 2528-5726.

Ismail, B \& Hadiyan, Y. (2008). Initial evaluation of the sengon (Falcataria moluccana) progeny test at 8 months in Kediri, East Java. Journal of Forest Plant Breeding 2 (3): 1-7.

Junaedi, A. (2018). Growth of A. cadamba (Anthocephalus cadamba Miq.) On marginal land of ultisol soil type in Riau. JPTH 12 (1): 51-63.

Kinho J. 2015. Evaluation of the growth of one-year-old Ebony (Diospyros Rumphii) progeny test plants in the nursery. Pros Sem Nas Masy Biodiv Indon. 1 (4): 800-804.

Kien, N.D., Jansson, G., Harwood, C. \& Thinh, H.H. (2009). Genetic Control of Growth and Form in Eucalyptus urophylla in Northern Vietnam. Journal of Tropical Forest Science $2 \mathbf{1}(\mathbf{1})$ 50-65.

Krisnawati, H., Kallio, M. \& Kaninnen, M. (2011). Anthocephallus cadamba Miq: Ecology, Silviculture and Productivity. Bogor (ID): CIFOR

Mulyana, D. (2010). Get to know Jabon Red and White Wood (2-36 H). Complete Guide to Jabon Timber Business and Planting. Agromedia Reader. Jakarta.

Na'iem. M. (2007). Hand Out Tree Breeding Course, Postgraduate Program at the Faculty of Forestry, Gadjah Mada University, Yogyakarta.

Prasetyawati, C.A. (2009). Evaluation of the 24-month-old Dyer half-sib Shorea parvifolia progeny test at PT. Sarmiento Parakantja Timber Central Kalimantan [Thesis]. Yogyakarta (ID): Gadjah Mada University.

Purwanta, S. (2012). Controlled Pollination and Teak Full-sib Heredity Test (Tectona grandis Lf). Thesis S-2. Forestry Science Study Program. Postgraduate Program, Faculty of Forestry, Gadjah Mada University. Yogyakarta.

Santos, P.E.T.D., Filho, P.E., Silva, L.T.D.M.D. \& Vandresen, P.B. (2015). Genetic variation for growth and selection in adult plants of Eucalyptus badjenensis. Gentic and Molecular Bio. 38 (4): 457-464.
Seo, J.W., Kim, H., Chun, J., Mansur, I. \& Lee, C.B. (2015). Silvicultural practice and growth of the Jabon tree (Anthocephalus cadamba Miq.) in the forests of West Java, Indonesia. f. of Agriculture E Life Science.

Setiadi, D. (2010). Genetic diversity of provenance test and Araucaria cunninghamii progeny test at the age of 18 months in Bondowoso, East Java. Fournal of Forest Plant Breeding 4 (1): 1-8.

Setiadi, D. \& Susanto, M. (2012). Genetic variation on provenance - progeny test of Araucaria cunninghamii At Bondowoso-East Java. JPTH 6 (3): 157-166.

Sumardi., Kartikawati, N.K., Prastyono. \& Rimbawanto, A. (2018). Genetic selection and acquisition in the second generation Kayuputih (Melaleuca cajuputi subsp. Cajuputi) Progeny test in Gunungkidul. Fournal of Forest Plant Breeding 12: 065-073.

Surip., Indrioko, S., Nirsatmanto, A. \& Setyaji, T. (2017). Effect of Selection on Genetic Obtaining in First Generation (F-1) Jabon Merah (Anthocephalus Macrophyllus (roxb.) Havil) progeny test in Wonogiri. Fournal of Forest Plant Breeding 11: 033-034.

Mahfudz., Na'iem, M., Sumardi. \& Hardiyanto, E.B. (2010). Growth variation in the merbau progeny test (Intsia bijuga O.Ktze) in Sobang, Banten. FPTH 4 (3): 157-165.

Mahfudz. (2013). Growth variation in the combination of two merbau test breeds (Intsia Bijuga O. Ktze) in Sobang, Banten and Bintuni, West Papua. BPK Info fournal Manado 3 (2): 131-145.

Mashudi. \& Baskorowati, L. (2015). Estimation of genetic parameters at two years old of Alstonia scholaris program trial at Gunungkidul Yogyakarta. FPTH 9 (1): 1-11.

Yudohartono, M. P. (2013). Jabon growth characteristics of the Sumbawa provenan at the semai level and after planting. Forest Plant Breeding fournal 7 (2): 85-96.

White, T.L., Adams, W.T. \& Neale, D.B. (2007). Forest Genetics. CABI Publishing, Oxfordshire-UK. 
Appendix 1. Analysis of diversity for plant height and diameter characters.

\begin{tabular}{|c|c|c|c|c|c|}
\hline Source & Type III Sum of Squares & Df & Mean Square & $\mathrm{F}$ & Sig. \\
\hline \multicolumn{6}{|c|}{ Parameter Height (m) } \\
\hline Corrected Model & $14140.252 \mathrm{a}$ & 319 & 44.327 & 7.450 & .000 \\
\hline Intercept & 20424.038 & 1 & 20424.038 & 3432.726 & .000 \\
\hline Family & 1605.997 & 79 & 20.329 & 3.417 & .000 \\
\hline Block & 7808.492 & 3 & 2602.831 & 437.465 & .000 \\
\hline Family * Block & 4725.763 & 237 & 19.940 & 3.351 & .000 \\
\hline Error & 5711.810 & 960 & 5.950 & & \\
\hline Total & 40276.100 & 1280 & & & \\
\hline Corrected Total & 19852.062 & 1279 & & & \\
\hline \multicolumn{6}{|c|}{ Diameter Parameters (cm) } \\
\hline Corrected Model & $17491.205 a$ & 319 & 54.831 & 5.950 & .000 \\
\hline Intercept & 24647.220 & 1 & 24647.220 & 2674.686 & .000 \\
\hline Family & 2027.759 & 79 & 25.668 & 2.785 & .000 \\
\hline Block & 9761.297 & 3 & 3253.766 & 353.095 & .000 \\
\hline Family * Block & 5702.148 & 237 & 24.060 & 2.611 & .000 \\
\hline Error & 8846.395 & 960 & 9.215 & & \\
\hline Total & 50984.820 & 1280 & & & \\
\hline Corrected Total & 26337.600 & 1279 & & & \\
\hline
\end{tabular}

R Squared $($ height $)=.712($ Adjusted R Squared $=.617), \mathrm{R}$ Squared $($ Diameter $)=.664($ Adjusted R Squared $=.553)$

Appendix 2. Variance components of family and individual heritability (plant height and diameter) of Samama trees.

\begin{tabular}{|l|l|l|l|l|l|}
\hline \multirow{2}{*}{ Character } & \multicolumn{3}{|c|}{ Variance Component } & \multirow{2}{*}{$\mathrm{h}^{2} \mathrm{i}$} & \multirow{2}{*}{$\mathrm{h}^{2} \mathrm{f}$} \\
\cline { 2 - 4 } & Family & Family in blok & Family in plot & & \\
\hline High & 0.20 & 0.92 & 3.26 & 0.8811 & 0.7123 \\
& $(4.50 \%)$ & $(21 \%)$ & $(74.50 \%)$ & & \\
\hline Diameter & 0.25 & 0.83 & 6.73 & 0.4406 & 0.5204 \\
& $(3.20 \%)$ & $(10.60 \%)$ & $(86.20 \%)$ & & \\
& & & & & \\
\hline
\end{tabular}

Note: Figures in parentheses are the proportion (\%) of the variance component to the total phenotypic variance 